Article

\title{
Chemical Compositions of Propolis from China and the United States and their Antimicrobial Activities Against Penicillium notatum
}

\author{
Xiaolan $\mathrm{Xu}{ }^{1,+}$, Ruixue $\mathrm{Pu}^{2,3,+}$, Yujie $\mathrm{Li}^{2,3}$, Zhenghong $\mathrm{Wu}^{1,3}$, Chunxia $\mathrm{Li}^{1}{ }^{1}$, Xiaoqing Miao ${ }^{1,3}$ \\ and Wenchao Yang ${ }^{1, *}$ \\ 1 College of Animal Science (College of Bee Science), Fujian Agriculture and Forestry University, \\ Fuzhou 350002, China; xlxufz@fafu.edu.cn (X.X.); wzh516@126.com (Z.W.); \\ 18887266780@139.com (C.L.); mxqsf88@126.com (X.M.) \\ 2 College of Food Science, Fujian Agriculture and Forestry University, Fuzhou 350002, China; \\ puruixue66@126.com (R.P.); 18105041302@163.com (Y.L.) \\ 3 Bee Product Processing and Application Research Center of the Ministry of Education, Fuzhou 350002, China \\ * Correspondence: beesyang@gmail.com; Tel.: +86-59183789426 \\ + These authors contributed equally to this work.
}

Received: 5 September 2019; Accepted: 30 September 2019; Published: 4 October 2019

\begin{abstract}
The chemical compositions of ethanol extracts of propolis from China (EEP-C) and the United States (EEP-A) and their antifungal activity against Penicillium notatum were determined. The result showed that a total of 49 compounds were detected by UPLC-Q-TOF-MS, 30 of which were present in samples from two regions. The major compounds of EEP-C and EEP-A were similar, including pinocembrin, pinobanksin-3-O-acetate, galanin, chrysin, pinobanksin, and pinobanksin-methyl ether, and both of them showed antifungal activity against $P$. notatum with same minimum inhibitory concentration (MIC) value of $0.8 \mathrm{mg} \cdot \mathrm{mL}^{-1}$. In the presence of propolis, the mycelial growth was inhibited, the hyphae became shriveled and wrinkled, the extracellular conductivities were increased, and the activities of succinate dehydrogenase (SDH) and malate dehydrogenase (MDH) were decreased. In addition, iTRAQ-based quantitative proteomic analysis of $P$. notatum in response to propolis revealed that a total of 341 proteins were differentially expressed, of which $88(25.8 \%)$ were upregulated and 253 (74.2\%) were downregulated. Meanwhile, the differentially expressed proteins (DEPs) involved in energy production and conversion, carbohydrate transport and metabolism, and the sterol biosynthetic pathway were identified. This study revealed that propolis could affect respiration, interfere with energy metabolism, and influence steroid biosynthesis to inhibit the growth of P. notatum.
\end{abstract}

Keywords: propolis; chemical composition; Penicillium notatum; antimicrobial activity; iTRAQ

\section{Introduction}

Propolis is a mixture of complex compounds, including flavonoids, phenolic acids, terpenes, coumarins, steroids, amino acids, and mineral elements, which are collected by bees and mixed with its saliva and beeswax [1]. Among them, flavonoids, terpenoids, and phenolic constituents have been reported as the main propolis components that contribute to antimicrobial activity [2-6]. Because the bioactive compound composition of propolis depends on the season, plant species, and the regions of collection, different types of propolis show different chemical composition resulting in different antimicrobial activities against bacterial and fungal pathogens [7-11].

Propolis has broad-spectrum antimicrobial activity against a variety of bacteria and fungi, such as Escherichia coli, Streptococcus mutans, and Staphylococcus aureus, exhibiting great potential for 
development as an antimicrobial drug without toxicity [2,12-14]. Many researchers have explored the antimicrobial activity of propolis. Pinocembrin from propolis could inhibit the respiration of fungi by interfering with energy metabolism and damaging the cell ultrastructure $[4,15]$. Propolis can induce cell death by regulating the metacaspase and ras signaling pathways, which occur in the transition from yeast-like to hyphal growth [16].

Penicillium notatum is a common fungus that not only causes fruit decay but also causes allergies in humans $[17,18]$, but there are few reports on the antifungal activity against $P$. notatum. In the current study, propolis was analyzed for antifungal activities against $P$. notatum in vitro tests. In addition, isobaric tagging for relative and absolute quantitation (iTRAQ) technology, which could be used to analyze the mode of action of the drugs or fungicide against fungal, such as Aspergillus fumigatus and Fusarium graminearum $[19,20]$, was used to analyze the antifungal activities at the protein level.

\section{Results}

\subsection{Chemical Composition}

The contents of total polyphenols and total flavonoids in propolis are shown in Table 1. The results showed that the content of total flavonoids and phenols of ethanol extracts of propolis from China (EEP-C) were higher than those of ethanol extracts of propolis from United States (EEP-A).

Table 1. Total phenol and flavonoid contents of propolis and bud poplar resins.

\begin{tabular}{|c|c|c|}
\hline Samples & Total Phenol (mg.g $\left.{ }^{-1}\right)$ & Total Flavonoids (mg.g ${ }^{-1}$ ) \\
\hline EEP-A & $370.19 \pm 4.12 b$ & $197.93 \pm 1.24 c$ \\
\hline EEP-C & $440.18 \pm 5.11 a$ & $305.60 \pm 1.69 b$ \\
\hline
\end{tabular}

EEP-A: ethanol extracts of propolis from United States, EEP-C: ethanol extracts of propolis from China. Note: different letters in the same column indicate significant differences between groups $(p<0.05)$.

The chromatograms obtained by UPLC-Q-TOF-MS are shown in Figure 1. EEP-A and EEP-C exhibited similar chemical profiles containing a high amount of flavonoids $(73.27 \%$ in EEP-A and $71.92 \%$ in EEP-C). A total of 49 constituents were identified in EEP-A (39) and EEP-C (42), 30 of which were present in two samples (Table 2). Besides, the major components in the two samples were similar, including pinocembrin (16.14\% in EEP-A and 9.66\% in EEP-C), pinobanksin-3-O-acetate $(14.52 \%$ in EEP-A and $11.40 \%$ in EEP-C), galangin (9.74\% in EEP-A and $9.90 \%$ in EEP-C), chrysin (8.33\% in EEP-A and $9.07 \%$ in EEP-C), pinobanksin (5.68\% in EEP-A and 6.26\% in EEP-C), and pinobanksin-methyl ether $(5.36 \%$ in EEP-A and $4.24 \%$ in EEP-C). 
Table 2. Main components of EEP-A and EEP-C.

\begin{tabular}{|c|c|c|c|c|c|c|c|c|c|c|}
\hline No & $\begin{array}{c}\mathrm{tR} \\
(\mathrm{min})\end{array}$ & $\lambda \max (\mathrm{nm})$ & Selected Ion & Formula & $\begin{array}{c}\text { Measured } \\
\text { Mass }\end{array}$ & $\begin{array}{l}\text { Calculated } \\
\text { Mass }\end{array}$ & $\begin{array}{l}\text { Mass Error } \\
\text { (MD) }\end{array}$ & MS/MS Fragmentation & Compound Name & Relative Area(\%) \\
\hline 1 & 2.66 & 238,281 & {$[\mathrm{M}-\mathrm{H}]$} & $\mathrm{C}_{7} \mathrm{H}_{6} \mathrm{O}_{3}$ & 137.0245 & 137.0239 & 0.6 & 137.0245 & $p$-Hydroxybenzoic acid (b) & $0.02 \%(\mathrm{C})$ \\
\hline 2 & 3.29 & 243,324 & {$[\mathrm{M}-\mathrm{H}]$} & $\mathrm{C}_{9} \mathrm{H}_{8} \mathrm{O}_{4}$ & 179.0351 & 179.0344 & 0.7 & $179.0344,161.0243,135.0448$ & Caffeic acid $(\mathrm{b}, \mathrm{c})$ & $0.06 \%(\mathrm{~A}), 0.45 \%(\mathrm{C})$ \\
\hline 3 & 4.61 & 237,310 & {$[\mathrm{M}-\mathrm{H}]$} & $\mathrm{C}_{9} \mathrm{H}_{8} \mathrm{O}_{3}$ & 163.0400 & 163.0395 & 0.5 & $163.0400,119.0502,93.0368$ & $p$-Coumaric acid $(\mathrm{b}, \mathrm{c})$ & $1.31 \%(\mathrm{~A}), 0.15 \%(\mathrm{C})$ \\
\hline 4 & 5.20 & 243,323 & {$[\mathrm{M}-\mathrm{H}]$} & $\mathrm{C}_{10} \mathrm{H}_{10} \mathrm{O}_{4}$ & 193.0505 & 193.0505 & 0 & 193.0505,133.0291 & Isoferulic acid $(\mathrm{b}, \mathrm{c})$ & $0.04 \%(\mathrm{C})$ \\
\hline 5 & 7.71 & 265,320 & {$[\mathrm{M}-\mathrm{H}]$} & $\mathrm{C}_{21} \mathrm{H}_{20} \mathrm{O}_{10}$ & 431.1013 & 431.0978 & 3.5 & $431.1013,268.0394$ & Apigenin-7-O- $\beta$-D-glucopyranoside ${ }^{(b)}$ & $0.27 \%(\mathrm{~A}), 0.35 \%(\mathrm{C})$ \\
\hline 6 & 8.29 & 250,365 & {$[\mathrm{M}-\mathrm{H}]$} & $\mathrm{C}_{16} \mathrm{H}_{11} \mathrm{O}_{6}$ & 299.0581 & 299.0556 & 2.5 & $299.0581,227.0363,129.0349$ & Kaempferol-methyl ether ${ }^{(b)}$ & $0.13 \%(\mathrm{~A}), 0.09 \%(\mathrm{C})$ \\
\hline 7 & 8.51 & 292 & {$[\mathrm{M}-\mathrm{H}]$} & $\mathrm{C}_{16} \mathrm{H}_{14} \mathrm{O}_{5}$ & 285.0783 & 285.0763 & 2.0 & $\begin{array}{c}\text { 285.0783, 267.0668, 252.0437, } \\
239.0722,138.0326\end{array}$ & Pinobanksin-methyl ether (b) & $0.24 \%(C)$ \\
\hline 8 & 8.63 & 250,365 & {$[\mathrm{M}-\mathrm{H}]$} & $\mathrm{C}_{17} \mathrm{H}_{14} \mathrm{O}_{7}$ & 329.0683 & 329.0661 & 2.4 & $\begin{array}{l}\text { 329.0683, 314.0441, 299.0209, } \\
271.0246,135.0458\end{array}$ & Quercetin-dimethyl ether ${ }^{(b)}$ & $0.03 \%(\mathrm{~A}), 0.05 \%(\mathrm{C})$ \\
\hline 9 & 8.92 & 292 & {$[\mathrm{M}-\mathrm{H}]$} & $\mathrm{C}_{16} \mathrm{H}_{14} \mathrm{O}_{5}$ & 285.0779 & 285.0763 & 1.6 & $269.04620,139.0406,124.0170$ & Pinobanksin-5-methyl ether $(b, c)$ & $0.13 \%$ (A), $0.15 \%$ (C) \\
\hline 10 & 8.92 & 251,349 & {$[\mathrm{M}-\mathrm{H}]$} & $\mathrm{C}_{15} \mathrm{H}_{10} \mathrm{O}_{6}$ & 285.0418 & 285.0399 & 1.9 & $269.0462,151.0039$ & Luteolin $(a, b)$ & $0.13 \%(\mathrm{~A}), 0.15 \%(\mathrm{C})$ \\
\hline 11 & 9.02 & 253,372 & {$[\mathrm{M}-\mathrm{H}]$} & $\mathrm{C}_{15} \mathrm{H}_{10} \mathrm{O}_{7}$ & 301.0365 & 301.0348 & 1.7 & $243.02886,151.00304$ & Quercetin $(\mathrm{a}, \mathrm{b})$ & $0.15 \%(\mathrm{~A}), 0.17 \%(\mathrm{C})$ \\
\hline 12 & 9.20 & 287 & {$[\mathrm{M}-\mathrm{H}]$} & $\mathrm{C}_{16} \mathrm{H}_{14} \mathrm{O}_{5}$ & 285.0778 & 285.0763 & 1.5 & $\begin{array}{l}285.0778,267.0667,252.0432 \\
239.0716,138.0325\end{array}$ & Pinobanksin-methyl ether isomer ${ }^{(b)}$ & $5.36 \%(\mathrm{~A}), 4.24 \%(\mathrm{C})$ \\
\hline 13 & 9.74 & 255,352 & {$[\mathrm{M}-\mathrm{H}]$} & $\mathrm{C}_{16} \mathrm{H}_{11} \mathrm{O}_{7}$ & 315.0514 & 315.0505 & 0.9 & $315.0514,300.0277$ & Quercetin-3-methyl ether $(b, c)$ & $0.61 \%(\mathrm{~A}), 1.00 \%(\mathrm{C})$ \\
\hline 14 & 10.44 & 265,312 & {$[\mathrm{M}-\mathrm{H}]$} & $\mathrm{C}_{16} \mathrm{H}_{12} \mathrm{O}_{4}$ & 267.0663 & 267.0657 & 0.6 & $252.0424,224.0476$ & Chrysin-5-methyl ether $(\mathrm{b}, \mathrm{c})$ & $0.74 \%$ (A), $0.21 \%$ (C) \\
\hline 15 & 10.94 & 292 & {$[\mathrm{M}-\mathrm{H}]$} & $\mathrm{C}_{15} \mathrm{H}_{12} \mathrm{O}_{5}$ & 271.0613 & 271.0606 & 0.7 & $271.0613,253.0504$ & Pinobanksin $(b, c)$ & $5.68 \%(\mathrm{~A}), 6.26 \%(\mathrm{C})$ \\
\hline 16 & 11.40 & 265,365 & {$[\mathrm{M}-\mathrm{H}]$} & $\mathrm{C}_{15} \mathrm{H}_{10} \mathrm{O}_{6}$ & 285.0400 & 285.0399 & 0.1 & $285.0400,227.03402$ & Kaempferol $(\mathrm{a}, \mathrm{b})$ & $0.74 \%(\mathrm{~A}), 0.21 \%(\mathrm{C})$ \\
\hline 17 & 11.44 & 285 & {$[\mathrm{M}-\mathrm{H}]$} & $\mathrm{C}_{16} \mathrm{H}_{14} \mathrm{O}_{4}$ & 269.0813 & 269.0814 & -0.1 & $\begin{array}{c}269.0813,254.0571,227.0701 \\
165.0186\end{array}$ & Pinocembrin-5-methyl ether $(\mathrm{b}, \mathrm{c})$ & $1.22 \%$ (A), $0.26 \%$ (C) \\
\hline 18 & 11.90 & 251,366 & {$[\mathrm{M}-\mathrm{H}]$} & $\mathrm{C}_{16} \mathrm{H}_{11} \mathrm{O}_{7}$ & 315.0504 & 315.0505 & -0.1 & $315.05045,300.02677,151.00311$ & Isorhamnetin $(\mathrm{b}, \mathrm{c})$ & $0.60 \%$ (A), $0.53 \%$ (C) \\
\hline 19 & 12.43 & 266,349 & {$[\mathrm{M}-\mathrm{H}]$} & $\mathrm{C}_{16} \mathrm{H}_{11} \mathrm{O}_{6}$ & 299.0555 & 299.0556 & -0.1 & $299.0555,284.03186$ & Kaempferol-3-methyl ether ${ }^{(b, c)}$ & $1.08 \%(\mathrm{~A}), 0.99 \%(\mathrm{C})$ \\
\hline 20 & 13.06 & 251,351 & {$[\mathrm{M}-\mathrm{H}]$} & $\mathrm{C}_{17} \mathrm{H}_{14} \mathrm{O}_{7}$ & 329.0664 & 329.0661 & 0.3 & $\begin{array}{l}\text { 329.0664, 314.0426, 299.0193 } \\
271.0246,133.0291\end{array}$ & Quercetin-dimethyl ether isomer ${ }^{(b, c)}$ & $1.30 \%(\mathrm{~A}), 1.29 \%(\mathrm{C})$ \\
\hline 21 & 13.85 & 259,350 & {$[\mathrm{M}-\mathrm{H}]$} & $\mathrm{C}_{16} \mathrm{H}_{12} \mathrm{O}_{5}$ & 283.0618 & 283.0606 & 1.2 & $283.0618,268.0379,239.0352$ & Galangin-5-methyl ether $(b, c)$ & $2.10 \%(\mathrm{~A}), 2.56 \%(\mathrm{C})$ \\
\hline 22 & 14.13 & 292 & {$[\mathrm{M}-\mathrm{H}]$} & $\mathrm{C}_{18} \mathrm{H}_{16} \mathrm{O}_{6}$ & 327.0880 & 327.0869 & 1.1 & $285.0768,252.0429$ & $\begin{array}{l}\text { Pinobanksin-5-methyl } \\
\text { ether-3-O-acetate }(\mathrm{b}, \mathrm{c})\end{array}$ & $0.41 \%(\mathrm{~A}), 0.26 \%(\mathrm{C})$ \\
\hline 23 & 14.94 & 251,365 & {$[\mathrm{M}-\mathrm{H}]$} & $\mathrm{C}_{16} \mathrm{H}_{11} \mathrm{O}_{6}$ & 299.0557 & 299.0556 & 0.1 & $299.0557,284.0322,151.0027$ & Kaempferol-7-methyl ether (b) & $0.11 \%(C)$ \\
\hline 24 & 16.12 & 251,366 & {$[\mathrm{M}-\mathrm{H}]$} & $\mathrm{C}_{17} \mathrm{H}_{14} \mathrm{O}_{7}$ & 329.0665 & 329.0661 & 0.4 & $\begin{array}{l}\text { 329.0660, 314.0411, 299.0186 } \\
271.0246,161.0235\end{array}$ & Quercetin-dimethyl ether isomer ${ }^{(b)}$ & $0.57 \%(\mathrm{~A})$ \\
\hline 25 & 16.55 & 251,351 & {$[\mathrm{M}-\mathrm{H}]$} & $\mathrm{C}_{17} \mathrm{H}_{14} \mathrm{O}_{7}$ & 329.0664 & 329.0661 & 0.3 & $\begin{array}{l}\text { 329.0664, 314.0426, 299.0193 } \\
271.0246,133.0292\end{array}$ & Quercetin-dimethyl ether isomer ${ }^{(b)}$ & $0.79 \%(\mathrm{C})$ \\
\hline 26 & 17.53 & 324 & {$[\mathrm{M}-\mathrm{H}]$} & $\mathrm{C}_{14} \mathrm{H}_{16} \mathrm{O}_{4}$ & 247.0971 & 247.0970 & 0.1 & $\begin{array}{c}247.0971,179.0341,161.0236 \\
135.0443\end{array}$ & Caffeic acid isoprenyl ester $(b, c)$ & $2.75 \%(C)$ \\
\hline 27 & 17.75 & 251,350 & {$[\mathrm{M}-\mathrm{H}]$} & $\mathrm{C}_{18} \mathrm{H}_{16} \mathrm{O}_{7}$ & 343.0818 & 343.0818 & 0 & $\begin{array}{c}343.0818,328.0579,313.0345 \\
298.0113\end{array}$ & Quercetin-trimethyl ether ${ }^{(b)}$ & $0.69 \%(\mathrm{~A})$ \\
\hline 28 & 18.03 & 267,313 & {$[\mathrm{M}-\mathrm{H}]$} & $\mathrm{C}_{15} \mathrm{H}_{10} \mathrm{O}_{4}$ & 253.0511 & 253.0501 & 1.0 & $145.0294,107.0138$ & Chrysin $(a, b)$ & $8.33 \%(\mathrm{~A}), 9.07 \%(\mathrm{C})$ \\
\hline 29 & 18.25 & 324 & {$[\mathrm{M}-\mathrm{H}]$} & $\mathrm{C}_{14} \mathrm{H}_{16} \mathrm{O}_{4}$ & 247.0977 & 247.0970 & 0.7 & $179.0346,161.0241,135.0449$ & Caffeic acid isoprenyl ester isomer $(b, c)$ & $1.48 \%(\mathrm{C})$ \\
\hline 30 & 18.52 & 324 & {$[\mathrm{M}-\mathrm{H}]$} & $\mathrm{C}_{16} \mathrm{H}_{14} \mathrm{O}_{4}$ & 269.0821 & 269.0814 & 0.7 & $269.0821,179.9343 \mathrm{~m} 133.0294$ & Caffeic acid benzyl ester $(b, c)$ & $0.88 \%(\mathrm{~A}), 1.91 \%(\mathrm{C})$ \\
\hline 31 & 19.00 & 286 & {$[\mathrm{M}-\mathrm{H}]$} & $\mathrm{C}_{15} \mathrm{H}_{12} \mathrm{O}_{4}$ & 255.0662 & 255.0657 & 0.5 & $213.0552,151.0031,107.0134$ & Pinocembrin $(b, c)$ & $16.14 \%(\mathrm{~A}), 9.66 \%(\mathrm{C})$ \\
\hline 32 & 19.65 & 265,361 & {$[\mathrm{M}-\mathrm{H}]$} & $\mathrm{C}_{15} \mathrm{H}_{10} \mathrm{O}_{5}$ & 269.0456 & 269.0450 & 0.6 & $211.03914,145.0288,117.0340$ & Galangin $(a, b)$ & $9.74 \%(\mathrm{~A}), 9.90 \%(\mathrm{C})$ \\
\hline 33 & 20.67 & 292 & {$[\mathrm{M}-\mathrm{H}]$} & $\mathrm{C}_{17} \mathrm{H}_{14} \mathrm{O}_{6}$ & 313.0745 & 313.0712 & 3.3 & $253.0505,119.0498$ & Pinobanksin-3-O-acetate $(\mathrm{b}, \mathrm{c})$ & $14.52 \%(\mathrm{~A}), 11.40 \%(\mathrm{C})$ \\
\hline
\end{tabular}


Table 2. Cont

\begin{tabular}{|c|c|c|c|c|c|c|c|c|c|c|}
\hline No & $\begin{array}{c}\mathbf{t R} \\
(\min )\end{array}$ & $\lambda \max (\mathrm{nm})$ & Selected Ion & Formula & $\begin{array}{l}\text { Measured } \\
\text { Mass }\end{array}$ & $\begin{array}{l}\text { Calculated } \\
\text { Mass }\end{array}$ & $\begin{array}{l}\text { Mass Error } \\
\text { (MD) }\end{array}$ & MS/MS Fragmentation & Compound Name & Relative Area(\%) \\
\hline 34 & 20.88 & 324 & {$[\mathrm{M}-\mathrm{H}]$} & $\mathrm{C}_{17} \mathrm{H}_{16} \mathrm{O}_{4}$ & 283.0975 & 283.0970 & 0.5 & $179.0347,161.0240,135.0447$ & Phenethyl caffeate $(\mathrm{b}, \mathrm{c})$ & $2.96 \%(C)$ \\
\hline 35 & 21.46 & 265,323 & {$[\mathrm{M}-\mathrm{H}]$} & $\mathrm{C}_{16} \mathrm{H}_{12} \mathrm{O}_{5}$ & 283.0611 & 283.0606 & 0.5 & $283.0611,268.03733,239.0346$ & Acacetin $(b, c)$ & $2.00 \%(\mathrm{~A}), 2.77 \%(\mathrm{C})$ \\
\hline 36 & 23.98 & 310 & {$[\mathrm{M}-\mathrm{H}]$} & $\mathrm{C}_{16} \mathrm{H}_{14} \mathrm{O}_{3}$ & 253.0866 & 253.0865 & 0.1 & $145.0287,117.0339$ & $p$-Coumaric acid benzyl ester ${ }^{(b, d)}$ & $3.46 \%(\mathrm{~A})$ \\
\hline 37 & 24.08 & 292 & {$[\mathrm{M}-\mathrm{H}]$} & $\mathrm{C}_{22} \mathrm{H}_{22} \mathrm{O}_{8}$ & 461.1248 & 461.1236 & 1.2 & $401.1012,253.0874$ & $\begin{array}{l}\text { Pinobanksin-3-O-acetate } \\
\text {-5-O-phydroxyphenylpropionate }(\mathrm{b}, \mathrm{c})\end{array}$ & $0.48 \%(C)$ \\
\hline 38 & 24.88 & 324 & {$[\mathrm{M}-\mathrm{H}]$} & $\mathrm{C}_{18} \mathrm{H}_{16} \mathrm{O}_{4}$ & 295.0984 & 295.0970 & 1.4 & $178.0270,133.0296$ & Caffeic acid cinnamyl ester $(\mathrm{b}, \mathrm{c})$ & $2.63 \%(\mathrm{~A}), 5.00 \%(\mathrm{C})$ \\
\hline 39 & 26.42 & 292 & {$[\mathrm{M}-\mathrm{H}]$} & $\mathrm{C}_{18} \mathrm{H}_{16} \mathrm{O}_{6}$ & 327.0874 & 327.0869 & 0.5 & $271.0604,253.0504$ & Pinobanksin-3-O-propionate ${ }^{(b, c)}$ & $1.41 \%(\mathrm{~A}), 5.50 \%(\mathrm{C})$ \\
\hline 40 & 26.34 & 310 & {$[\mathrm{M}-\mathrm{H}]$} & $\mathrm{C}_{18} \mathrm{H}_{16} \mathrm{O}_{3}$ & 267.1021 & 267.1021 & 0 & $163.0390,145.0288,119.0495$ & $p$-Coumaric acid benylethyl ester (b) & $0.51 \%(\mathrm{~A})$ \\
\hline 41 & 30.80 & 310 & {$[\mathrm{M}-\mathrm{H}]$} & $\mathrm{C}_{18} \mathrm{H}_{16} \mathrm{O}_{3}$ & 279.1027 & 279.1021 & 0.6 & $235.1120,134.0355,163.0028$ & $p$-Coumaric cinnamyl ester $(\mathrm{b}, \mathrm{d})$ & $6.25 \%(\mathrm{~A})$ \\
\hline 42 & 32.13 & 292 & {$[\mathrm{M}-\mathrm{H}]$} & $\mathrm{C}_{19} \mathrm{H}_{18} \mathrm{O}_{6}$ & 341.1036 & 341.1025 & 1.1 & $271.0610,253.0509$ & Pinobanksin-3-O-butyrate $(\mathrm{b}, \mathrm{c})$ & $3.23 \%(C)$ \\
\hline 43 & 32.65 & 292 & {$[\mathrm{M}-\mathrm{H}]$} & $\mathrm{C}_{20} \mathrm{H}_{18} \mathrm{O}_{6}$ & 353.1039 & 353.1025 & 1.4 & $297.1532,253.0511$ & Pinobanksin-3-O-pentenoate $(\mathrm{b}, \mathrm{c})$ & $0.72 \%(\mathrm{~A})$ \\
\hline 44 & 33.38 & 292 & {$[\mathrm{M}-\mathrm{H}]$} & $\mathrm{C}_{27} \mathrm{H}_{24} \mathrm{O}_{8}$ & 475.1397 & 475.1393 & 0.4 & $415.1174,264.0500,134.0366$ & $\begin{array}{l}\text { Pinobanksin-3-O-acetate- } \\
\text { 5-O-phydroxyphenylpropionate }{ }^{(b, c)}\end{array}$ & $0.18 \%(\mathrm{~A})$ \\
\hline 45 & 33.89 & 292 & {$[\mathrm{M}-\mathrm{H}]$} & $\mathrm{C}_{22} \mathrm{H}_{16} \mathrm{O}_{6}$ & 375.0894 & 375.0869 & 2.5 & $271.0603,253.0504$ & Pinobanksin-3-O-benzoate ${ }^{(\mathrm{b})}$ & $1.53 \%(\mathrm{~A})$ \\
\hline 46 & 35.98 & 292 & {$[\mathrm{M}-\mathrm{H}]$} & $\mathrm{C}_{20} \mathrm{H}_{20} \mathrm{O}_{6}$ & 355.1207 & 355.1182 & 2.5 & $253.0520,271.0619$ & $\begin{array}{l}\text { Pinobanksin-3-O-pentanoate or } \\
\text { 2-methylbutyrateb }{ }^{(b, c)}\end{array}$ & $0.13 \%(\mathrm{~A}), 2.85 \%(\mathrm{C})$ \\
\hline 47 & 36.68 & 292 & {$[\mathrm{M}-\mathrm{H}]$} & $\mathrm{C}_{21} \mathrm{H}_{20} \mathrm{O}_{6}$ & 367.1205 & 367.1182 & 2.3 & $271.0624,253.0512$ & Pinobanksin-O-hexenoate ${ }^{b, c}$ & $0.56 \%(C)$ \\
\hline 48 & 37.43 & 292 & {$[\mathrm{M}-\mathrm{H}]$} & $\mathrm{C}_{24} \mathrm{H}_{20} \mathrm{O}_{6}$ & 403.1200 & 403.1182 & 1.8 & $297.1132,271.0614,253.0513$ & $\begin{array}{c}\text { Pinobanksin-3-O-phenylpropionate } \\
(\mathrm{b}, \mathrm{c})\end{array}$ & $0.20 \%(\mathrm{~A}), 0.19 \%(\mathrm{C})$ \\
\hline 49 & 38.69 & 292 & {$[\mathrm{M}-\mathrm{H}]$} & $\mathrm{C}_{21} \mathrm{H}_{22} \mathrm{O}_{6}$ & 369.1352 & 369.1338 & 1.4 & $271.0612,253.0511$ & Pinobanksin-3-O-hexanoate ${ }^{(b, c)}$ & $1.08 \%(\mathrm{~A}), 0.84 \%(\mathrm{C})$ \\
\hline
\end{tabular}

tR(min): Retention time (min); $\lambda$ max: the maximum absorption wavelength. ${ }^{a}$ Confirmed with the standard; ${ }^{\mathrm{b}}$ confirmed with MS fragmentation; ${ }^{\mathrm{c}}$ confirmed with references [21]; ${ }^{\mathrm{d}}$ confirmed with references [22]; ${ }^{\mathrm{e}}$ confirmed with references [23]; ${ }^{\mathrm{f}}$ confirmed with references [24] 


\subsection{Antifungal Activities}

The antifungal effects of EEP against P. notatum are shown in Table 3 . The values of diameters of inhibition zones showed that EEP-A and EEP-C had antifungal activity. The inhibitory diameter of EEP-A and EEP-C were $8.65 \mathrm{~cm}$ to $14.88 \mathrm{~cm}$ and $11.79 \mathrm{~cm}$ to $16.62 \mathrm{~cm}$, respectively. In addition, their minimum inhibitory concentration (MIC) was the same, both of which were $0.8 \mathrm{mg} \cdot \mathrm{mL}^{-1}$.

Table 3. The diameters of inhibition zones.

\begin{tabular}{|c|c|c|c|c|c|c|}
\hline & \multicolumn{5}{|c|}{ Concentration $\left(\mathrm{mg} \cdot \mathrm{mL}^{-1}\right)$} & \multirow{2}{*}{$\begin{array}{c}\text { MIC } \\
\left(\mathrm{mg} \cdot \mathrm{mL}^{-1}\right)\end{array}$} \\
\hline & 20 & 40 & 60 & 80 & 100 & \\
\hline EEP-A & $8.65 \pm 0.83 h$ & $10.33 \pm 1.04 \mathrm{~g}$ & $12.09 \pm 0.95 \mathrm{e}$ & $13.66 \pm 1.04 \mathrm{~d}$ & $14.88 \pm 2.05 c$ & 0.8 \\
\hline EEP-C & $11.79 \pm 1.09 \mathrm{e}$ & $13.74 \pm 0.04 d$ & $14.28 \pm 2.11 \mathrm{~d}$ & $15.16 \pm 0.94 b$ & $16.62 \pm 1.77 \mathrm{a}$ & 0.8 \\
\hline $70 \%$ ethanol & & & $7.04 \pm 0.14$ & & & - \\
\hline
\end{tabular}

MIC: minimum inhibitory concentration. Note: different letters indicate significant differences between groups $(p<0.05)$.
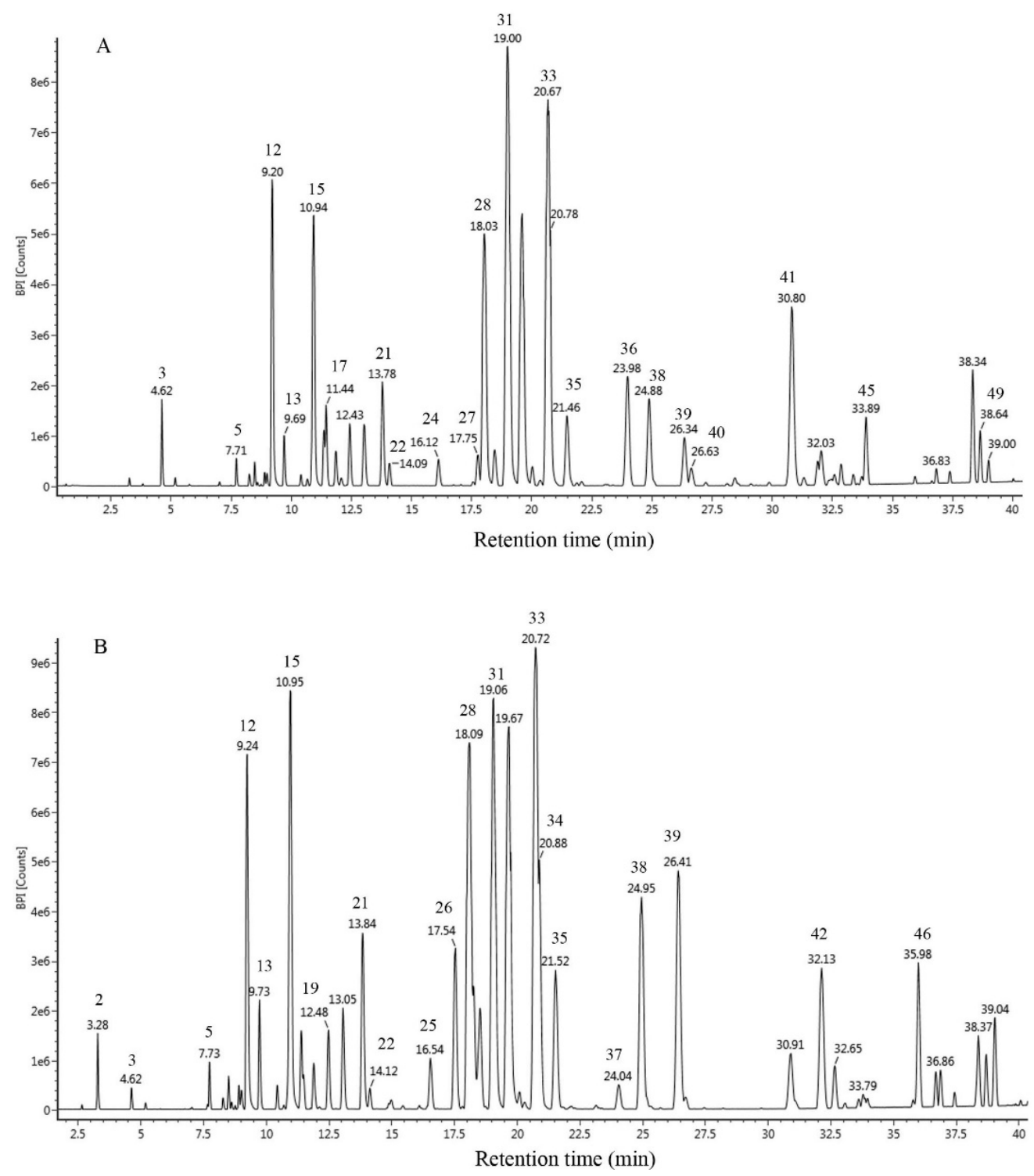

Figure 1. Chromatographic profile of propolis from the United States (A) and China (B) using UPLC-Q-TOF-MS. 


\subsection{Effects of EEP on Mycelial Growth}

As shown in Figure 2, the mycelia of the control group were in the period of slow growth from 0 to $48 \mathrm{~h}$, and in the logarithmic phase from 48 to $96 \mathrm{~h}$, and the dry weight reached a maximum at $96 \mathrm{~h}$. EEP-A and EEP-C treatment significantly inhibited mycelial growth, and EEP-C had a stronger inhibitory effect than EEP-A. According to the results of the growth curve, the mycelia that were cultured for 3 days were used for the following experiments.

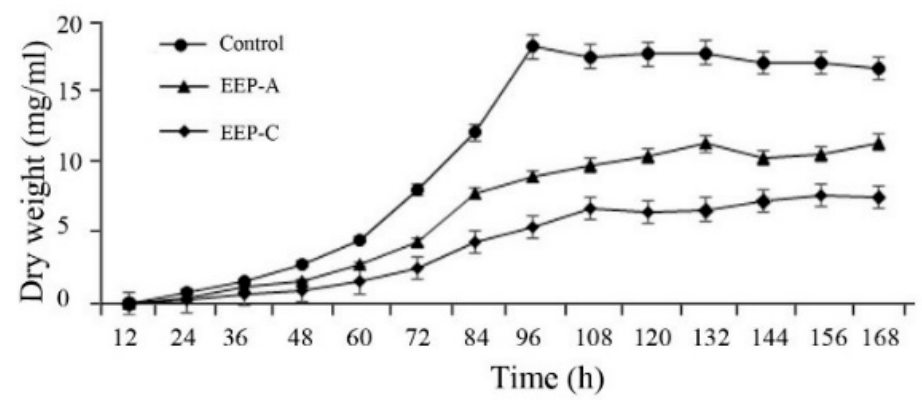

Figure 2. Effect of ethanol extracts of propolis (EEP) on the mycelial growth of P. notatum.

The morphological changes in hyphae were observed by scanning electron microscopy (Figure 3). The hyphae of the control group were round and full with a smooth surface. While the hyphae of EEP groups were deformed, their surfaces were rough, and the structures were damaged. The results show that propolis can effectively destroy the structure and morphology of hyphae at 1/2 MIC to inhibit the growth of mycelium.
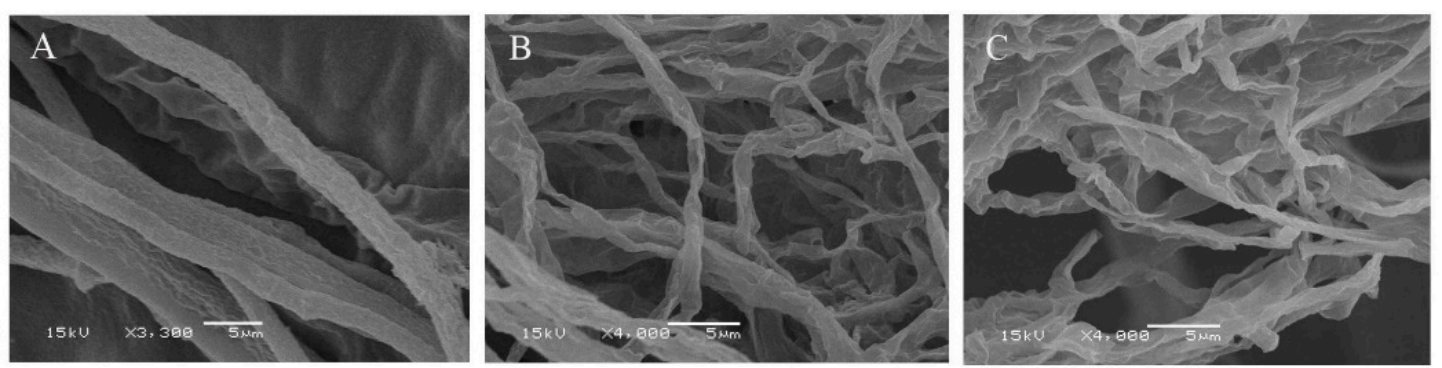

Figure 3. Effect of propolis on the hyphal morphology of P. notatum. (A) Control, (B) ethanol extracts of propolis from United States (EEP-A), (C) ethanol extracts of propolis from China (EEP-C).

\subsection{Effect of EEP on the Cell Membrane Permeability}

As shown in Figure 4, compared with the control, EEP treatment increased the extracellular conductivity, indicating that EEP could damage the cell membrane.

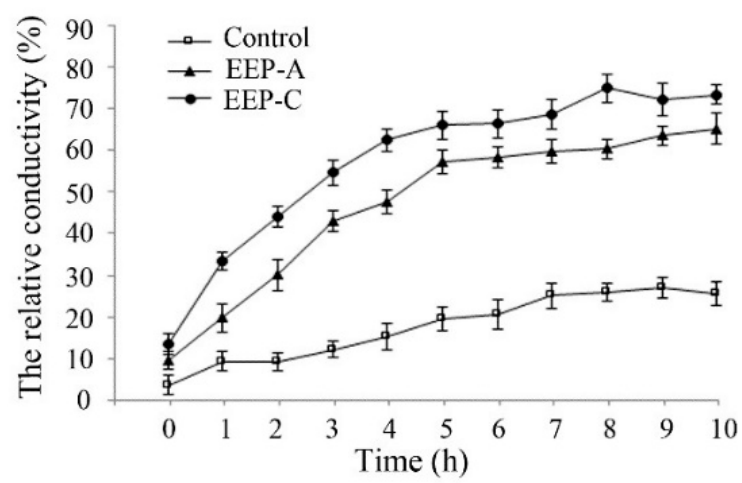

Figure 4. Effect of EEP on the cell membrane permeability of P. notatum. 
2.5. Effect of EEP on the Activities of Succinate Dehydrogenase (SDH) and Malate Dehydrogenase (MDH)

As shown in Figure 5, SDH and MDH activities of the EEP treatment groups decreased significantly, indicating that propolis could interfere with the respiration of P. notatum.

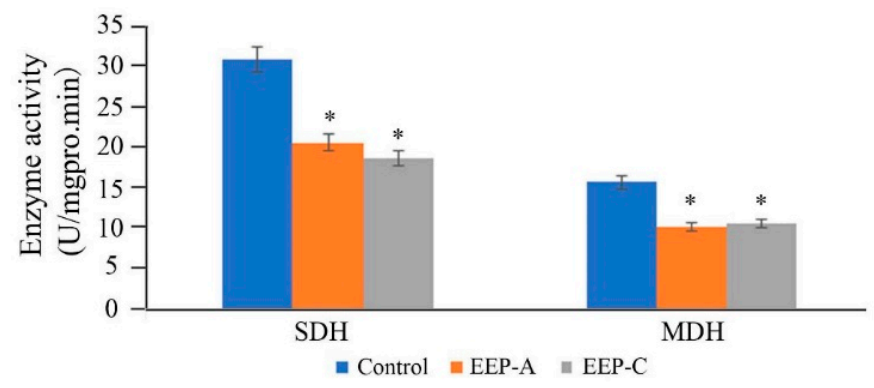

Figure 5. Effect of propolis on succinate dehydrogenase (SDH) and malate dehydrogenase (MDH) activities of $P$. notatum $\left(n=3,{ }^{*} p<0.05\right)$.

\section{6. iTRAQ Data Analysis and Differentially Expressed Proteins (DEPS) Identification}

EEP-C was used for proteomics experiment; as a result, a total of 341 DEPs were identified in the P. notatum proteome in response to propolis, of which 88 (25.8\%) were upregulated and $253(74.2 \%)$ were downregulated. According to the Clusters of Orthologous Groups of proteins (COG) functional categories, the DEPs are divided into 23 functional categories (Supplementary Figure S1). Part of the iTRAQ data is listed in Supplementary Table S2, and more detailed information, including protein sequences, can be found in Supplementary Table S3.

\subsection{RT-PCR Analysis of the Differentially Expressed Proteins}

To validate the reliability of the iTRAQ data, the expression levels of 10 genes were randomly selected for qRT-PCR assays (Figure 6). The results showed that the expression levels detected by qRT-PCR were consistent with the iTRAQ data, indicating that the qRT-PCR data estimate the reliability of the results from the iTRAQ analysis.

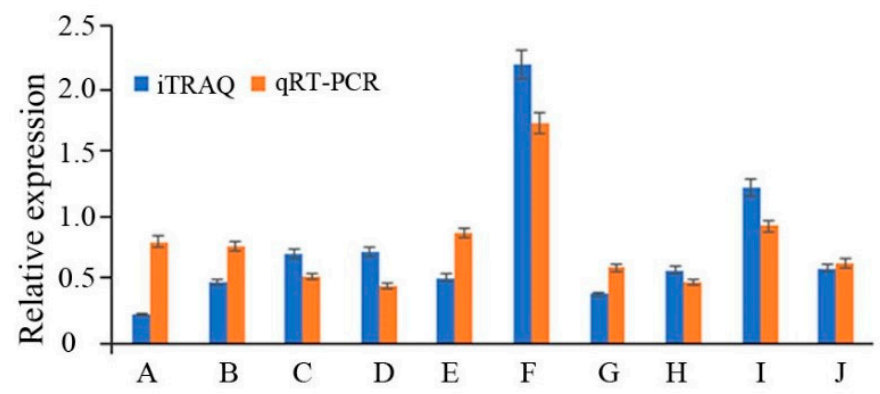

Figure 6. Comparative analysis of RNA and protein levels of differentially expressed proteins. A. sterol C-24 reductase (ERG4), B. 40S ribosomal protein S8, C. translation initiation factor 1A, D. zinc finger, E. tubulin alpha chain, F. acyl-CoA N-acyltransferase, G. nicotinamide adenine dinucleotide (NADH) ubiquinone oxidoreductase, $\mathbf{H}$. flavin adenine dinucleotide (FAD)-dependent pyridine nucleotide-disulfide oxidoreductase, I. ATPase P-type $\mathrm{Mg} / \mathrm{Cd} / \mathrm{Cu} / \mathrm{Zn} / \mathrm{Na} / \mathrm{Ca} / \mathrm{Na} / \mathrm{H}$-transporter, J. serine/threonine-protein phosphatase.

\section{Materials and Methods}

\subsection{Propolis Samples}

P. notatum AS 3.3871 was purchased from Shanghai Benno Biotechnology Co., Ltd. (Shanghai, China). Propolis from China was supplied by Fujian Shenfeng Technology Development Co., Ltd. (Fuzhou, Fujian, China). Propolis from the United States was collected in Michigan in May 2016. 


\subsection{Preparation of Experimental Samples}

Row propolis was extracted using ethanol $(70 \%, v / v)$ by the ultrasonic wave method with the parameters of $40 \mathrm{kHz}, 20 \mathrm{~min}$, and $60{ }^{\circ} \mathrm{C} 3$ times and then soaked at room temperature for 2 days. The mixture was centrifuged, and the supernatant was partially evaporated under low pressure. After the concentrated propolis extract was stored at $4{ }^{\circ} \mathrm{C}$, beeswax solidified on the surface. This process was repeated three times to remove the beeswax. Finally, the ethanol extract of propolis (EEP) was concentrated under vacuum until the solvent evaporated. The samples were named EEP-C (Chinese propolis) and EEP-A (U.S. propolis).

\subsection{Total Polyphenol and Total Flavonoid Contents Determination}

The Folin-Ciocalteu method was used for the quantification of total polyphenol in each propolis sample [25]. Gallic acid was used as a standard substance. The absorbance of samples was measured at $765 \mathrm{~nm}$, and the total phenolic content was estimated using a calibration curve $\left(\mathrm{Y}=0.0015 \mathrm{X}-0.0074, \mathrm{R}^{2}=0.999\right)$. The content was expressed in milligram equivalents of gallic acid/gram of dry propolis extract.

The total flavonoid content in the extracts was determined according to the national standards for propolis in China (GB/T 24283-2018). Rutin was used as a standard substance, and the absorbance of samples was measured at $510 \mathrm{~nm}\left(\mathrm{Y}=0.005 \mathrm{X}-0.004, \mathrm{R}^{2}=0.999\right)$.

\subsection{UPLC-ESI-MS Analysis}

EEP (0.2 g) were dissolved with $80 \%$ aqueous solution of methanol $(20 \mathrm{~mL})$. The extracts were centrifuged at 14,000 rpm for $5 \mathrm{~min}$ and diluted 10 times for chemical analyses.

Chemical analyses were performed on a Waters UPLC system using an ACQUITY UPLC HSS T3 column $(2.1 \times 100 \mathrm{~mm}, 1.7 \mu \mathrm{m})$. The mobile phases A and B consisted of $0.1 \%$ formic acid in water and acetonitrile, respectively. The mobile phase gradient program was as follows: 0 8 $\mathrm{min}, 90 \% \mathrm{~A} \sim 70 \% \mathrm{~A}$; 8 30 min, 70\% A 55\% A; 30 38 $\mathrm{min}, 55 \%$ A 40\% A; 38 42 min, 40\% A 30\% A; 42 44 min, 30\% A 20\% A, $44 \sim 45 \mathrm{~min}, 20 \%$ A $~ 0$ A; 45 47.5 $\mathrm{min}, 0 \mathrm{~A} ; 47.6 \mathrm{~min}, 90 \% \mathrm{~A} ; 47.6 \sim 50 \mathrm{~min}, 90 \% \mathrm{~A}$. The flow rate was $0.36 \mathrm{~mL} / \mathrm{min}$. The on-line UV spectra were recorded at $254 \mathrm{~nm}, 280 \mathrm{~nm}$, and $330 \mathrm{~nm}$; meanwhile, the samples were scanned from $200 \mathrm{~nm}$ to $400 \mathrm{~nm}$.

The mass spectra were acquired in both positive and negative ion modes by using a Waters definition accurate-mass quadrupole time-of-flight (Q-TOF) Xevo G2-XS mass spectrometer (Waters Ltd., Elstree, Hertfordshire, UK) equipped with an ESI source. The optimized operating parameters were as follows: mass range, $m / z$ 500-1500; the flow rate of drying gas (N2), $800 \mathrm{~L} / \mathrm{h}$; drying gas temperature, $400{ }^{\circ} \mathrm{C}$; cone gas flow, $100 \mathrm{~L} / \mathrm{h}$; source temperature, $120{ }^{\circ} \mathrm{C}$; capillary voltage, $2.5 \mathrm{kV}$; cone voltage, $40 \mathrm{~V}$. In mass spectrometry (MSE) mode, the energies for collision-induced dissociation (CID) were $6 \mathrm{~V}$ for the precursor ion at low energy mode and 30-160 V for fragmentation information at high energy mode. An external reference (Lock-Spray TM) consisting of a $0.2 \mathrm{ng} / \mathrm{mL}$ solution of Leucine enkephalin was used in both positive $\left(m / z 556.2771[\mathrm{M}+\mathrm{H}]^{+}\right)$and negative mode $\left(\mathrm{m} / z 554.2615[\mathrm{M}-\mathrm{H}]^{-}\right)$, infused at a flow of $5 \mu \mathrm{L} / \mathrm{min}$. All the data were acquired using Mass Lynx TM 4.1 software (Waters, Milford, MA, USA).

\subsection{Antifungal Bioassay}

In vitro antifungal activity was evaluated by measuring the diameter of the inhibition zone according to Ajay Sharma's method [26]. The spores were suspended in distilled water containing Tween-80 $(0.1 \%, \mathrm{v} / \mathrm{v})$ to a final density of $1 \times 105 \mathrm{CFU} / \mathrm{mL}$ and cultivated on a potato dextrose agar (PDA) plate using the spread plate method. An Oxford cup was used to create a well in the agar plate. Then, $50 \mu \mathrm{L}$ of each EEP solution $(0,20,40,60,80,100 \mathrm{mg} / \mathrm{mL})$ was added to the wells, and ethanol $(70 \%, \mathrm{v} / \mathrm{v})$ only was added to the wells as a control. After the plates were incubated at $28^{\circ} \mathrm{C}$ for 7 days, the diameters of the inhibition zones were measured. 
The minimum inhibitory concentration (MIC) values were determined by the agar dilution method. One milliliter of EEP was added to $19 \mathrm{~mL}$ of PDA medium, and $5 \mu \mathrm{L}$ of spore suspension was injected into the center of the solidified medium. PDA without EEP was used as a control. The plates were incubated at $28{ }^{\circ} \mathrm{C}$ for 3 days; the concentration that could completely inhibit microbial growth was considered the MIC.

\subsection{Culture Conditions}

The spore suspension was added to potato dextrose broth (PDB) medium at a final concentration of $1 \times 10^{5} \mathrm{CFU} \cdot \mathrm{mL}^{-1}$, EEPs were added to the medium at a final concentration of $1 / 2 \mathrm{MIC}$, and ethanol $(70 \%, v / v)$ was added to the medium as a control. The mycelia were incubated at $28^{\circ} \mathrm{C}$ and $180 \mathrm{rpm}$ for 7 days, and the dry weight of the mycelia was weighed every $12 \mathrm{~h}$ to evaluate the effect of propolis on mycelial growth. The mycelia in the logarithmic growth period were used in the following experiments.

\subsection{Scanning Electron Microscope (SEM) Observation}

The hyphae were fixed with $5 \%$ glutaric dialdehyde and $1 \%$ osmic acid for $4 \mathrm{~h}$. After treatment with 50\%,70\%,80\%,90\%, and 100\% alcohol for dehydration, the hyphae were observed under SEM by JSM-6380LV (JEOL Co., Tokyo, Japan).

\subsection{Effects of EEP on mycelia Cell Membrane Permeability}

The mycelia were placed in $100 \mathrm{~mL}$ of sterile water. Then, EEPs were added to the water at a final concentration of $1 / 2 \mathrm{MIC}$. The different treatment groups were cultured at $28{ }^{\circ} \mathrm{C}$, and the electrical conductivities of the EEP treatment group (Pn) and control group (P0) were determined once every $1 \mathrm{~h}$. The treatment group was boiled for $10 \mathrm{~min}$ and cooled to determine the electrical conductivity of the mycelium (Pk). An equal concentration of ethanol was used as a control. The electrical conductivity was calculated using the following formula:

The electrical conductivity $(\%)=(\mathrm{Pn}-\mathrm{P} 0) /(\mathrm{Pk}-\mathrm{P} 0) \times 100 \%$

\subsection{Enzyme Activity Assays}

The effects of EEP on SDH and MDH were determined. The mycelia were ground in phosphate buffer $\left(0.1 \mathrm{~mol} \cdot \mathrm{L}^{-1}, \mathrm{pH} 7.5\right)$. After centrifugation, the supernatants were collected to detect the enzyme activity according to the procedure of the enzyme reagent kits (Nanjing Jiancheng Bioeng. Inst., Nanjing, Jiangsu, China), and the protein content of the hyphae was determined using the Bradford method (Nanjing Jiancheng Bioeng. Inst., Nanjing, Jiangsu, China). The enzyme activities were expressed as units per milligram of protein.

\subsection{0. iTRAQ Experiment}

The spore suspension was added to PDA liquid medium to yield a final density of $1 \times 10^{6} \mathrm{FU} / \mathrm{mL}$, and then EEPs were added to obtain a final concentration of 1/2 MIC. An equal volume of ethanol $(70 \%, v / v)$ instead of EEP was used as a control. The fungus was incubated at $28{ }^{\circ} \mathrm{C}$ for 3 days, and the hyphae were suspended in lysis buffer (7 M urea; $2 \mathrm{M}$ thiourea; 4\% CHAPS; $40 \mathrm{mM}$ Tris- $\mathrm{HCl}$, pH 8.5; 1 mM PMSF; 2 mM EDTA) and sonicated on ice. The proteins were reduced with $10 \mathrm{mM}$ DTT at $56{ }^{\circ} \mathrm{C}$ for $1 \mathrm{~h}$ and then alkylated by $55 \mathrm{mM}$ iodoacetamide (IAM) in a dark room for $1 \mathrm{~h}$. The reduced and alkylated protein mixtures were precipitated by adding $4 \times$ volume of chilled acetone at $-20^{\circ} \mathrm{C}$ overnight. After centrifugation at $4{ }^{\circ} \mathrm{C}$ and $30,000 \times g$, the pellet was dissolved in $0.5 \mathrm{M}$ triethylammonium bicarbonate (TEAB) (Applied Biosystems, Milan, Italy) and sonicated on ice. After centrifuging at $30,000 \times g$ at $4{ }^{\circ} \mathrm{C}$, an aliquot of the supernatant was taken to determine protein concentration. The proteins in the supernatant were kept at $-80{ }^{\circ} \mathrm{C}$ for further analysis.

Total protein $(100 \mu \mathrm{g})$ was removed from each sample, and then the protein was digested with Trypsin Gold (Promega, Madison, WI, USA). Peptides were processed according to the manufacturer's 
protocol for 8-plex iTRAQ reagent (Applied Biosystems, Milan, Italy). SCX chromatography was performed with an LC-20AB HPLC pump system (Shimadzu, Kyoto, Japan). Data acquisition was performed with a TripleTOF 5600 System (AB SCIEX, Concord, ON, Canada) fitted with a Nanospray III source (AB SCIEX, Concord, ON, Canada) and a pulled quartz tip as the emitter (New Objectives, Woburn, MA, USA).

The iTRAQ data were analyzed using Mascot software (version 2.3.02, Matrix Science Inc., Boston, MA, USA). Functional annotations of the proteins were conducted using the Blast2GO program against the non-redundant protein database (NR, NCBI). The Kyoto Encyclopedia of Genes and Genomes (KEGG) database and the KOG database (NCBI) were used to classify and group the identified proteins.

\subsection{Quantitative Real-Time PCR}

Total RNA was extracted using Trizol reagent (Invitrogen, Carlsbad, CA, USA). cDNA synthesis was performed using the PrimeScript ${ }^{\mathrm{TM}}$ RT reagent kit with gDNA Eraser (TaKaRa). qPCR was performed using the SYBR ${ }^{\circledR}$ Premix ExTaq ${ }^{\mathrm{TM}}$ kit (TaKaRa). The PCR primers were designed using primer software 6.0, and the sequences are listed in Supplementary Table S1. PCRs were performed using the Applied Biosystems 7500 Real-Time PCR System. The cycling conditions were $94{ }^{\circ} \mathrm{C}$ for 3 min followed by 40 cycles at $94^{\circ} \mathrm{C}$ for $30 \mathrm{~s}$ and $60^{\circ} \mathrm{C}$ for $34 \mathrm{~s}$. To standardize the target gene level with respect to variability in the quality of RNA and cDNA, GAPDH was amplified under the same conditions as an internal control.

\subsection{Statistical Analysis}

All experiments were performed in triplicate. The data are reported as the mean $(n=3) \pm$ standard deviation. The differences among groups were tested by paired-samples T-test of SPSS software $\left(\right.$ IBM $^{\circledR}$ SPSS $^{\circledR}$ Statistics, versus 19.0). Differences of $p<0.05$ were considered statistically significant.

\section{Discussion}

In this study, the concentrations of total phenols, flavonoids, and chemical composition of propolis, as well as their antifungal activities, were determined, and propolis from China and the United States had an indifferent chemical composition and antifungal activities. It has been reported that the antifungal effect of propolis extract is mainly attributed to the flavonoid and phenolic components [3,27], especially chrysin, galanin, cinnamic acid, caffeic acid, and their derivatives [28-32]. In this study, the major compounds of both regions were pinocembrin, galanin, chrysin, etc., and the results were consistent with previous studies of polar-type propolis [33,34]. So far, no studies have reported the composition of propolis from Michigan. It has been demonstrated that the propolis component is dependent on plant sources [34]. Polar tree (Populus spp.) is found in North America and China, and EEP-A showed similar peaks with EEP-C, indicating it also belongs to polar-type propolis. When the MIC value was in the range of $100-1000 \mathrm{mg} \mathrm{mL}^{-1}$ in vitro susceptibility tests, the propolis was thought to have antifungal properties [35,36]. The results revealed that EEP-A and EEP-C showed a potent effect against $P$. notatum.

EEP-A and EEP-C can inhibit the growth of mycelia, change the morphology of mycelia, and affect the relative permeability of mycelial cell membranes to destroy the formation of biofilms [37,38]. In the current study, most proteins related to mycelial growth, such as amino acid metabolism, translation, ribosomal structure, and biogenesis, were downregulated in the presence of propolis (Supplementary Table S3).

Of the 23 proteins involved in amino acid transport and metabolism, 18 were downregulated, and five were upregulated (Supplementary Table S2). Among them, tryptophan synthase, glutamine synthetase, and methionine synthase, which directly participate in the synthesis of amino acids, were downregulated, indicating that EEP can affect the synthesis and metabolism of amino acids. Of the 32 proteins involved in translation, ribosomal structure, and biogenesis, 24 were downregulated, and eight were upregulated. Among the 13 ribosomal proteins, only two were upregulated, and 
the others were downregulated. Ribosomal proteins and ribosomal RNA constitute the ribosome, play important roles in ribosomal assembly and protein synthesis [39], and also have many extrachromosomal functions, including DNA damage repair, gene expression regulation, mRNA translation, cell proliferation, differentiation, and apoptosis. Ribosomal protein deficiency can cause cell cycle arrest and apoptosis [40-42]. Amino acids are protein precursors, and ribosomes are the sites of protein synthesis; thus, the downregulation of the expression of these proteins also affects the synthesis of proteins, resulting in a decrease in the amount of the total protein.

EEP can reduce the activities of MDH and SDH, which are related to energy metabolism processes, including the tricarboxylic acid cycle and oxidative phosphorylation. In eukaryotic mitochondria, $\mathrm{MDH}$ and SDH are the key enzymes of glucose metabolism and the tricarboxylic acid cycle, respectively, which can be used as indicators of respiratory metabolism. Inhibition of the activity of microbial respiratory enzymes is one of the main mechanisms of some drugs against pathogenic fungi [43-46]. Yao et al. found that extracts of nobiletin and tangeretin could strongly inhibit the activities of SDH and MDH in Pseudomonas to inhibit the growth of mycelia [37].

In the proteome experiment, there were 25 proteins related to energy metabolism: three were upregulated, and the other 22 were downregulated (Supplementary Table S2). Among them, some proteins involved in the respiratory electron transport chain, including cytochrome c oxidase subunit $6 \mathrm{~A}$, nicotinamide adenine dinucleotide (NADH) dehydrogenase, NADH-ubiquinone oxidoreductase, and flavin adenine dinucleotide (FAD)/flavin Mononucleotide (FMN)-containing dehydrogenases, were downregulated after EEP treatment. Because the mitochondrial respiratory chain relates to energy metabolism, the inhibition of respiration would interfere with many physiological processes [47-50]. Currently, the respiratory chain in pathogenic fungi has been proposed as a potential antimicrobial target [51]. For example, antimycin A could bind to cytochrome c reductase in mitochondrial complex III and block the mitochondrial electron transfer between cytochrome $b$ and $\mathrm{c}$ to inhibit cell growth $[52,53]$. Inhibitors of the respiratory chain were also efficient in blocking the germination of $A$. fumigatus by inhibiting protein synthesis [54].

The inhibition of the respiratory chain would lead to a decrease in the cellular levels of ATP production and cause cell death $[55,56]$. In this study, proteins that are involved in the tricarboxylic acid cycle (TCA cycle) were downregulated, including isocitrate dehydrogenase (IDH), succinyl-CoA synthetase, and pyruvate dehydrogenase complex (PDHC) (Supplementary Table S2). TCA is the common pathway through which sugars, proteins, and fats are completely oxidized to produce ATP. Moreover, the intermediate products in this cycle (such as oxaloacetic acid and $\alpha$-ketoglutaric acid) are materials for the synthesis of sugar, amino acids, fats, etc. As a result, the TCA cycle exhibited a strong correlation with fungal growth $[57,58]$. IDH catalyzes isocitrate to produce ketoglutarate, NADH, and $\mathrm{CO}_{2}$. This reaction is a rate-limiting and irreversible step. Succinyl CoA synthetase could catalyze succinyl CoA to generate succinic acid and generate GTP. These two enzymes affect the production of ATP and thus interfere with energy metabolism. Besides, PDHC connects the aerobic oxidation of sugar with the TCA cycle and oxidative phosphorylation and plays a crucial role in the energy metabolism of the mitochondrial respiratory chain in cells [59]. The above results suggested that the respiration and energy metabolism of $P$. notatum interfered in response to EEP.

Besides, ergosterol, a fungus-specific sterol, enriched in cell plasma membranes, is an effective antifungal drug target. Amiodarone, fluconazole, naftifine hydrochloride, and terbinafine could inhibit the growth of mycelia by inhibiting the key enzymes in the synthetic pathway of sterol and interfering with the biosynthesis of ergosterol [60-62]. In this study, proteome analysis indicated that EEP could downregulate the ERG4 and ERG9 genes of the ergosterol biosynthesis pathway (Supplementary Table S2). The ERG4 gene encodes the sterol C-24 reductase, which catalyzes the conversion of ergosta-5,7,22,24-tetraenol to ergosterol in the final step of ergosterol biosynthesis. In Fusarium graminearum, ERG4 (FgERG4) deletion mutant could not synthesize ergosterol, resulting in a significant decrease in mycelial growth and conidiation and abnormal conidia production [63,64]. ERG9 (squalene synthase) is the first committed enzyme of the sterol biosynthesis pathway. The strain 
overexpressing the gene ERG9 also displayed significant inhibition of growth in the presence of ferrozine, calcium deprivation, and osmotic/ionic stress [65]. ERG4 and ERG9 play an important role in the process of sterol synthesis, and inhibitors of these enzymes have been intensively studied as potential antifungal agents; thus, their downregulation suggested that the synthesis of sterols of P. notatum were downregulated in response to EEP.

\section{Conclusions}

In this work, UPLC-Q-TOF-MS method was used to analyze the chemical compositions of ethanol extracts of propolis from China and the United States. The results showed that the propolis from two regions had a high content of flavonoids, which exhibited broad-spectrum antimicrobial activity against a variety of bacteria and fungi. In vitro test of EEP against $P$. notatum, EEP could inhibit the mycelial growth, destroy the hyphae structure and permeability of the cell membrane, and decrease the activities of succinate dehydrogenase (SDH) and malate dehydrogenase (MDH). Meanwhile, DEPs involved in energy production and conversion, carbohydrate transport and metabolism, and the sterol biosynthetic pathway were also identified. This study revealed that propolis could affect respiration, interfere with energy metabolism, and influence steroid biosynthesis to inhibit the growth of P. notatum.

Supplementary Materials: The following are available online. Supplementary Table S1. Primer pairs used for qRT-PCR expression analysis; Supplementary Table S2. Partial DEPs of P. notatum in response to EEP; Supplementary Table S3. DEPs of P. notatum in response to propolis; Supplementary Figure S1. COG functional categories of DEPs.

Author Contributions: X.X., W.Y., Z.W. and X.M. conceived and designed the experiments; R.P. and Y.L. performed the experiments; X.X. and R.P. analyzed the data; C.L. and W.Y. contributed reagents/materials/analysis tools; $X . X$. wrote the paper.

Funding: This research was supported by Fujian Agriculture and Forestry University under the grant of The Science and Technology Innovation Special Funding of Fujian Agriculture and Forestry University (KFA17519A) and Modern Agro-industry Technology Research System (CARS-44-KXJ20).

Conflicts of Interest: The authors declare no conflict of interest. The founding sponsors had no role in the design of the study; in the collection, analyses, or interpretation of data; in the writing of the manuscript, and in the decision to publish the results.

\section{References}

1. Athikomkulchai, S.; Awale, S.; Ruangrungsi, N.; Ruchirawat, S.; Kadota, S. Chemical constituents of Thai propolis. Fitoterapia 2013, 88, 96-100. [CrossRef] [PubMed]

2. Popova, M.P.; Graikou, K.; Chinou, I.; Bankova, V.S. GC-MS Profiling of Diterpene Compounds in Mediterranean Propolis from Greece. J. Agric. Food Chem. 2010, 58, 3167-3176. [CrossRef] [PubMed]

3. Funakoshi-Tago, M.; Okamoto, K.; Izumi, R.; Tago, K.; Yanagisawa, K.; Narukawa, Y.; Kiuchi, F.; Kasahara, T.; Tamura, H. Anti-inflammatory activity of flavonoids in Nepalese propolis is attributed to inhibition of the IL-33 signaling pathway. Int. Immunopharmacol. 2015, 25, 189-198. [CrossRef] [PubMed]

4. Boonsai, P.; Phuwapraisirisan, P.; Chanchao, C. Antibacterial Activity of a Cardanol from Thai Apis mellifera Propolis. Int. J. Med. Sci. 2014, 11, 327-336. [CrossRef] [PubMed]

5. Silva, M.S.S.; De Lima, S.G.; Oliveira, E.H.; Lopes, J.A.D.; Chaves, M.H.; Reis, F.A.M.; Citó, A.M.G.L. Anacardic acid derivatives from Brazilian propolis and their antibacterial activity. Eclética Química J. 2008, 33, 53-58. [CrossRef]

6. Sanpa, S.; Popova, M.; Bankova, V.; Tunkasiri, T.; Eitssayeam, S.; Chantawannakul, P. Antibacterial Compounds from Propolis of Tetragonula laeviceps and Tetrigona melanoleuca (Hymenoptera: Apidae) from Thailand. PLoS ONE 2015, 10, e0126886. [CrossRef] [PubMed]

7. Hamasaka, T.; Kumazawa, S.; Fujimoto, T.; Nakayama, T. Antioxidant Activity and Constituents of Propolis Collected in Various Areas of Japan. Food Sci. Technol. Res. 2004, 10, 86-92. [CrossRef]

8. Hatano, A.; Nonaka, T.; Yoshino, M.; Ahn, M.-R.; Tazawa, S.; Araki, Y.; Kumazawa, S. Antioxidant Activity and Phenolic Constituents of Red Propolis from Shandong, China. Food Sci. Technol. Res. 2012, 18, 577-584. [CrossRef] 
9. Kalogeropoulos, N.; Konteles, S.J.; Troullidou, E.; Mourtzinos, I.; Karathanos, V.T. Chemical composition, antioxidant activity and antimicrobial properties of propolis extracts from Greece and Cyprus. Food Chem. 2009, 116, 452-461. [CrossRef]

10. Laskar, R.A.; Sk, I.; Roy, N.; Begum, N.A. Antioxidant activity of Indian propolis and its chemical constituents. Food Chem. 2010, 122, 233-237. [CrossRef]

11. Bonvehí, J.S.; Gutiérrez, A.L. The antimicrobial effects of propolis collected in different regions in the basque country (northern spain). World J. Microbiol. E Biotechnol. 2012, 28, 1351-1358.

12. He, M.; Wu, T.; Pan, S.; Xu, X. Antimicrobial mechanism of flavonoids against Escherichia coli ATCC 25922 by model membrane study. Appl. Surf. Sci. 2014, 305, 515-521. [CrossRef]

13. da Cunha, M.G.; Franchin, M.; de Carvalho Galvão, L.C.; de Ruiz, A.L.; de Carvalho, J.E.; Ikegaki, M.; de Alencar, S.M.; Koo, H.; Rosalen, P.L. Antimicrobial and antiproliferative activities of stingless bee Melipona scutellaris geopropolis. BMC Complement. Altern. Med. 2013, 13, 23. [CrossRef] [PubMed]

14. Campos, J.F.; Dos Santos, U.P.; Macorini, L.F.B.; De Melo, A.M.M.F.; Balestieri, J.B.P.; Paredes-Gamero, E.J.; Cardoso, C.A.L.; Souza, K.D.P.; Dos Santos, E.L. Antimicrobial, antioxidant and cytotoxic activities of propolis from Melipona orbignyi (Hymenoptera, Apidae). Food Chem. Toxicol. 2014, 65, 374-380. [CrossRef] [PubMed]

15. Peng, L.; Yang, S.; Cheng, Y.J.; Chen, F.; Pan, S.; Fan, G. Antifungal activity and action mode of pinocembrin from propolis against Penicillium italicum. Food Sci. Biotechnol. 2012, 21, 1533-1539. [CrossRef]

16. De Castro, P.A.; Bom, V.L.P.; Brown, N.A.; De Almeida, R.S.C.; Ramalho, L.N.Z.; Savoldi, M.; Goldman, M.H.S.; Berretta, A.A.; Goldman, G.H. Identification of the cell targets important for propolis-induced cell death in Candida albicans. Fungal Genet. Boil. 2013, 60, 74-86. [CrossRef] [PubMed]

17. Gatto, M.A.; Ippolito, A.; Linsalata, V.; Cascarano, N.A.; Nigro, F.; Vanadia, S.; Venere, D.D. Activity of extracts from wild edible herbs against postharvest fungal diseases of fruit and vegetables. Postharvest Biol. Technol. 2012, 61, 72-82. [CrossRef]

18. Hou, Y.; Zheng, Z.; Xu, S.; Chen, C.; Zhou, M. Proteomic analysis of Fusarium graminearum treated by the fungicide JS399-19. Pestic. Biochem. Physiol. 2013, 107, 86-92. [CrossRef]

19. Cagas, S.E.; Jain, M.R.; Li, H.; Perlin, D.S. Profiling the Aspergillus fumigatus proteome in response to caspofungin. Antimicrob. Agents \& Chemother. 2011, 55, 146-154.

20. Cicco, N.; Lanorte, M.; Paraggio, M.; Viggiano, M.; Lattanzio, V. A reproducible, rapid and inexpensive Folin-Ciocalteu micro-method in determining phenolics of plant methanol extracts. Microchem. J. 2013, 91, 107-110. [CrossRef]

21. Falcao, S.I.; Vale, N.; Gomes, P.; Domingues, M.R.; Freire, C.; Cardoso, S.M.; Vilas-Boas, M. Phenolic Profiling of Portuguese Propolis by LC-MS Spectrometry: Uncommon Propolis Rich in Flavonoid Glycosides. Phytochemical Analysis. 2013, 24, 309-318. [CrossRef] [PubMed]

22. Gardana, C.; Scaglianti, M.; Pietta, P.; Simonetti, P. Analysis of the polyphenolic fraction of propolis from different sources by liquid chromatography-tandem mass spectrometry. J. Pharm. Biomed. Anal. 2007, 45, 390-399. [CrossRef] [PubMed]

23. Midorikawa, K.; Banskota, A.H.; Tezuka, Y.; Nagaoka, T.; Matsushige, K.; Message, D.; Huertas, A.A.G.; Kadota, S. Liquid chromatography-mass spectrometry analysis of propolis. Phytochem. Anal. 2001, 12, 366-373. [CrossRef] [PubMed]

24. Hayashi, K.; Komura, S.; Isaji, N.; Ohishi, N.; Yagi, K. Isolation of antioxidative compounds from Brazilian propolis: 3,4-dihydroxy-5-prenylcinnamic acid, a novel potent antioxidant. Chem. Pharm. Bull. 1999, 47, 1521-1524. [CrossRef]

25. Miguel, M.G.; Nunes, S.; Dandlen, S.A.; Cavaco, A.M.; Antunes, M.D. Phenols, flavonoids and antioxidant activity of aqueous and methanolic extracts of propolis (Apis mellifera L.) from Algarve, South Portugal. Food Sci. Technol. 2014, 34, 16-23. [CrossRef]

26. de Souza, E.L.; de Barros, J.C.; de Oliveira, C.E.; da Conceição, M.L. Influence of Origanum vulgare L. essential oil on enterotoxin production, membrane permeability and surface characteristics of Staphylococcus aureus. Int. J. Food Microbiol. 2010, 137, 308-311. [CrossRef] [PubMed]

27. Bonvehi, J.S.; Gutiérrez, A.L. Antioxidant Activity and Total Phenolics of Propolis from the Basque Country (Northeastern Spain). J. Am. Oil Chem. Soc. 2011, 88, 1387-1395. [CrossRef]

28. Uzel, A.; Sorkun, K.; Onçă̆, O.; Cogŭlu, D.; Gençay, O.; Salih, B. Chemical compositions and antimicrobial activities of four different Anatolian propolis samples. Microbiol. Res. 2005, 160, 189-195. [CrossRef] 
29. Mercan, N.; Kivrak, I.; Duru, M.E.; Katircioglu, H.; Gulcan, S.; Malci, S.; Acar, G.; Salih, B.; Malc1, S. Chemical composition effects onto antimicrobial and antioxidant activities of propolis collected from different regions of Turkey. Ann. Microbiol. 2006, 56, 373-378. [CrossRef]

30. Campana, R.; Patrone, V.; Franzini, I.T.M.; Diamantini, G.; Vittoria, E.; Baffone, W. Antimicrobial Activity of Two Propolis Samples Against Human Campylobacter jejuni. J. Med. Food 2009, 12, 1050-1056. [CrossRef]

31. Yang, S.; Peng, L.; Su, X.; Chen, F.; Cheng, Y.; Fan, G.; Pan, S. Bioassay-guided isolation and identification of antifungal components from propolis against Penicillium italicum. Food Chem. 2011, 127, 210-215. [CrossRef]

32. Salas, A.L.; Alberto, M.R.; Zampini, I.C.; Cuello, A.S.; Maldonado, L.; Ríos, J.L.; Schmeda-Hirschmann, G.; Isla, M.I. Biological activities of polyphenols-enriched propolis from Argentina arid regions. Phytomedicine 2016, 23, 27-31. [CrossRef] [PubMed]

33. Zhang, J.; Cao, X.; Ping, S.; Wang, K.; Shi, J.; Zhang, C.; Zheng, H.; Hu, F. Comparisons of Ethanol Extracts of Chinese Propolis (Poplar Type) and Poplar Gums Based on the Antioxidant Activities and Molecular Mechanism. Evid. -Based Complementary Altern. Med. 2015, 2015, 1-15. [CrossRef] [PubMed]

34. Huang, S.; Zhang, C.P.; Wang, K.; Li, G.Q.; Hu, F.L. Recent Advances in the Chemical Composition of Propolis. Molecules 2014, 19, 19610-19632. [CrossRef] [PubMed]

35. Popova, M.; Dimitrova, R.; Al-Lawati, H.; Tsvetkova, I.; Najdenski, H.; Bankova, V. Omani propolis: Chemical profiling, antibacterial activity and new propolis plant sources. Chem. Cent. J. 2013, 7, 158. [CrossRef] [PubMed]

36. Abreu, A.C.; Mcbain, A.J.; Simões, M. Plants as sources of new antimicrobials and resistance-modifying agents. Nat. Prod. Rep. 2012, 29, 1007-1021. [CrossRef] [PubMed]

37. Haghdoost, N.; Salehi, T.; Khosravi, A.; Sharifzadeh, A. Antifungal activity and influence of propolis against germ tube formation as a critical virulence attribute by clinical isolates of Candida albicans. J. De Mycol. Médicale 2016, 26, 298-305. [CrossRef] [PubMed]

38. Yao, X.; Zhu, X.; Pan, S.; Fang, Y.; Jiang, F.; Phillips, G.O.; Xu, X. Antimicrobial activity of nobiletin and tangeretin against Pseudomonas. Food Chem. 2012, 132, 1883-1890. [CrossRef]

39. Franklin, D.; Zhang, Y. Extra-Ribosome Functions of Ribosomal Proteins. Encycl. Cell Biol. 2016, $281-287$.

40. Zaher, H.S.; Green, R. Quality control by the ribosome following peptide bond formation. Nature. 2008, 457, 161-166. [CrossRef]

41. Warner, J.R.; McIntosh, K.B. How common are extraribosomal functions of ribosomal proteins? Mol. Cell 2009, 34, 3-11. [CrossRef] [PubMed]

42. Lindström, M.S.; Zhang, Y. Ribosomal protein S9 is a novel B23/NPM-binding protein required for normal cell proliferation. J. Boil. Chem. 2008, 283, 15568-15576. [CrossRef] [PubMed]

43. Hartman, T.; Weinrick, B.; Vilchèze, C.; Berney, M.; Tufariello, J.; Cook, G.M.; Jacobs, W.R. Succinate Dehydrogenase is the Regulator of Respiration in Mycobacterium tuberculosis. PLoS Pathog. 2014, 10, e1004510. [CrossRef] [PubMed]

44. Pecsi, I.; Hards, K.; Ekanayaka, N.; Berney, M.; Hartman, T.; Jacobs, W.R., Jr.; Cook, G.M. Essentiality of succinate dehydrogenase in mycobacterium smegmatis and its role in the generation of the membrane potential under hypoxia. Mbio 2014, 5, e01093-14. [CrossRef] [PubMed]

45. Yang, S.; Liu, L.; Li, D.; Xia, H.; Su, X.; Peng, L.; Pan, S. Use of active extracts of poplar buds against Penicillium italicum and possible modes of action. Food Chem. 2016, 196, 610-618. [CrossRef] [PubMed]

46. Han, X.; Tong, Y.; Tian, M.; Sun, X.; Wang, S.; Ding, C.; Yu, S. Characterization of the immunogenicity and pathogenicity of malate dehydrogenase in Brucella abortus. World J. Microbiol. Biotechnol. 2014, 30, 2063-2070. [CrossRef] [PubMed]

47. Saradhi, P.P.; Alia; Vani, B. Inhibition of mitochondrial electron transport is the prime cause behind proline accumulation during mineral deficiency in Oryza sativa. Plant Soil 1993, 155, 465-468. [CrossRef]

48. Puntel, R.L.; Roos, D.H.; Seeger, R.L.; Rocha, J.B.; Da Rocha, J.B.T. Mitochondrial electron transfer chain complexes inhibition by different organochalcogens. Toxicol. Vitr. 2013, 27, 59-70. [CrossRef]

49. Le, S.B.; Hailer, M.K.; Buhrow, S.; Wang, Q.; Flatten, K.; Pediaditakis, P.; Bible, K.C.; Lewis, L.D.; Sausville, E.A.; Pang, Y.-P.; et al. Inhibition of Mitochondrial Respiration as a Source of Adaphostin-induced Reactive Oxygen Species and Cytotoxicity. J. Boil. Chem. 2007, 282, 8860-8872. [CrossRef]

50. Obermeyer, G.; Fragner, L.; Lang, V.; Weckwerth, W. Dynamic adaption of metabolic pathways during germination and growth of lily pollen tubes after inhibition of the electron transport chain. Plant. Physiol. 2013, 162, 1822-1833. [CrossRef] 
51. Martins, V.D.P.; Dinamarco, T.M.; Curti, C.; Uyemura, S.A. Classical and alternative components of the mitochondrial respiratory chain in pathogenic fungi as potential therapeutic targets. J. Bioenerg. Biomembr. 2011, 43, 81-88. [CrossRef] [PubMed]

52. Han, Y.H.; Kim, S.H.; Kim, S.Z.; Park, W.H. Antimycin A as a mitochondrial electron transport inhibitor prevents the growth of human lung cancer A549 cells. Oncol. Rep. 2008, 20, 689-693. [CrossRef] [PubMed]

53. Ma, X.; Jin, M.; Cai, Y.; Xia, H.; Long, K.; Liu, J.; Yu, Q.; Yuan, J. Mitochondrial electron transport chain complex III is required for antimycin A to inhibit autophagy. Chem. Boil. 2011, 18, 1474-1481. [CrossRef] [PubMed]

54. Taubitz, A.; Bauer, B.; Heesemann, J.; Ebel, F. Role of Respiration in the Germination Process of the Pathogenic Mold Aspergillus fumigatus. Curr. Microbiol. 2007, 54, 354-360. [CrossRef] [PubMed]

55. Jaña, F.; Faini, F.; LaPier, M.; Pavani, M.; Kemmerling, U.; Morello, A.; Maya, J.D.; Jara, J.; Parra, E.; Ferreira, J. Tumor cell death induced by the inhibition of mitochondrial electron transport: The effect of 3-hydroxybakuchiol. Toxicol. Appl. Pharmacol. 2013, 272, 356-364. [CrossRef] [PubMed]

56. Jing, L.; Kumari, S.; Mendelev, N.; Li, P.A. Coenzyme Q10 Ameliorates Ultraviolet B Irradiation Induced Cell Death Through Inhibition of Mitochondrial Intrinsic Cell Death Pathway. Int. J. Mol. Sci. 2011, 12, 8302-8315. [CrossRef]

57. Heyland, J.; Fu, J.; Blank, L.M. Correlation between TCA cycle flux and glucose uptake rate during respiro-fermentative growth of Saccharomyces cerevisiae. Microbiol. 2009, 155, 3827-3837. [CrossRef]

58. Blank, L.M.; Sauer, U. TCA cycle activity in Saccharomyces cerevisiae is a function of the environmentally determined specific growth and glucose uptake rates. Microbiol. 2004, 150, 1085-1093. [CrossRef]

59. Patel, M.S.; Korotchkina, L.G. The biochemistry of the pyruvate dehydrogenase complex. Biochem. Mol. Biol. Educ. 2010, 31, 5-15.

60. Gamarra, S.; Rocha, E.M.; Zhang, Y.Q.; Park, S.; Rao, R.; Perlin, D.S. Mechanism of the synergistic effect of amiodarone and fluconazole in Candida alhicans. Antimicrob. Agents Chemot. 2010, 54, 1753-1761. [CrossRef]

61. Ghannoum, M.; Isham, N.; Verma, A.; Plaum, S.; Fleischer, A.; Hardas, B. In Vitro Antifungal Activity of Naftifine Hydrochloride against Dermatophytes. Antimicrob. Agents Chemother. 2013, 57, 4369-4372. [CrossRef] [PubMed]

62. Nowosielski, M.; Hoffmann, M.; Wyrwicz, L.S.; Stepniak, P.; Plewczynski, D.M.; Lazniewski, M.; Ginalski, K.; Rychlewski, L. Detailed Mechanism of Squalene Epoxidase Inhibition by Terbinafine. J. Chem. Inf. Model. 2011, 51, 455-462. [CrossRef] [PubMed]

63. Liu, X.; Jiang, J.; Yin, Y.; Ma, Z. Involvement of FgERG4 in ergosterol biosynthesis, vegetative differentiation and virulence in Fusarium graminearum. Mol. Plant Pathol. 2013, 14, 71-83. [CrossRef] [PubMed]

64. Long, N.; Xu, X.; Zeng, Q.; Sang, H.; Lu, L. Erg4A and Erg4B Are Required for Conidiation and Azole Resistance via Regulation of Ergosterol Biosynthesis in Aspergillus fumigatus. Appl. Environ. Microbiol. 2016, 83, e02924-16. [CrossRef] [PubMed]

65. Bhattacharya, S.; Esquivel, B.D.; White, T.C. Overexpression or Deletion of Ergosterol Biosynthesis Genes Alters Doubling Time, Response to Stress Agents, and Drug Susceptibility in Saccharomyces cerevisiae. mBio 2018, 9, e01291-18. [CrossRef] [PubMed]

Sample Availability: Samples of the compounds 2, 10, 11, 28 are available from the authors.

(C) 2019 by the authors. Licensee MDPI, Basel, Switzerland. This article is an open access article distributed under the terms and conditions of the Creative Commons Attribution (CC BY) license (http://creativecommons.org/licenses/by/4.0/). 